\title{
POST-SOVIET DISORDER : WAR IN CHECHNIA
}

\author{
BÜLENT GÖKAY
}

Today the Bolsheviks fear the dead Shamil more than the Vorontsovs and Bariatinskiis feared him as a live, but honourable enemy. - Editorial in Svobodnyi Kavkaz, No. 4 (1952). ${ }^{1}$

There will not be a Second Caucasian War. Shamil, his Murids and Gazavat will remain in the past. - Pavel Felgengauer, Sevodnia, 17 December $1994 .^{2}$

In the post-Cold War world, the focus of international security concern shifted from the nuclear stand-off between two super powers to the mosaic of deep ethnic tensions. Since the end of the Sovict system, it has become increasingly evident that the Caucasus is one of the most worrying trouble spots. There are half a dozen potential border disputes and more than twenty significant ethnic groups in the region. In this short article, I would like to concentrate on a recent dispute in the region: the war in Chechnia. I will outline some of the complexities of this fascinating question. I will try to identify the basis of age-long problems and draw some comparisons with the past and present.

\section{History:}

There was a saying in Persia: "When a shah is a fool, he attacks the Chechens". The people of Chechnia have been fighting since ad infinitum. They fought among themselves and against the invaders. Successive waves of would-be conquerors had found them a terrible foc. Roman legions, Arabs,

\footnotetext{
${ }^{1}$ In L. Tillett, The Great Friendship, Chapell Hill, 1969, p. 130.

2 Sevodnia, 17 December 1994 , p. 3.
} 
Attila, Genghis Khan, and the Persian Shah, all met their first check here in the North Caucasus.

For most of the time the events in this region went practically unnoticed in the West. In European eyes, the Caucasus was part of the Middle East. Utterly foreign, less civilised, exotic and exciting, but with very little direct relationship to the affairs of Europe. Many Europeans may have had the same feelings about the Balkans. But this region was too close to home to be ignored.

John le Carre, famous spy thriller author, writes recently that when he turned in the first draft of his recent novel, a distinguished literary agent asked him in good faith whether such places as Groznyi were made up names, or did they really exist!

I believe that it may be useful first to recall briefly the background and geography of this region. The North Caucasus region is one of the most ethnically and linguistically diverse regions in the world. Three main ethnolinguistic groups (Altaic, Indo-European, and Iberro-Caucasian) are represented in the region. The geography of the North Caucasus facilitated the preservation of this diversity: the mountainous terrain isolated the population groups, and created conditions for a multiplicity of languages and dialects.

Together with Daghestan, Chechnia forms the northeastern part of the Caucasus. Chechnia is a quadrangle between the Terek and Sunja rivers in the west and the north, the Andi range in the east and the main range in the south. Like other parts of the Caucasus, Chechnia is divided by parallel ranges. The heartland of Chechnia lies between the Sunja range and river and the 'black mountains'. It is, in fact, the widest of valleys situated in between the different ranges.

Chechnia is mainly populated by the Chechens. Their Russian name derives from the village of Great Chechan where the Russians first encountered them. The western and southwestern part of the country is inhabited by the Ingush. The two groups are so close to each other that according to some scholars they are separated only because of their different historical backgrounds.

Despitc the fragmentation of the North Caucasian population into various ethnic and linguistic groups, the inhabitants are unified by broad cultural similarities. Contact between North Caucasian groups extends back for centuries. The broad, North Caucasian identity was realised in a variety of alliances, from the nineteenth century Caucasian independence wars to the establishment of the North Caucasus Mountain Republic in 1918. 
The Chechens are characterised by the their strong sense of national and religious identity. They are a Muslim people. They speak a language of the North Caucasian group. The origins of the Chechens are unclear. They are probably an indigenous people of the North Caucasus. They originally lived in the mountains but began to move down to the plains from the end of the fourteenth century. By the late 16 th century many were settled along the banks of the River Sunzha. During the 16th century Islam was introduced amongst the Chechens.

Historically, the relations of the Chechens and the other North Caucasian people to Russia have been hostile. The historical memory of the North Caucasian peoples is closely tied to struggles against the Russians.

Prior to the mid-16th century, Russia had no significant contacts with the peoples of the North Caucasus. The situation changed as a result of Ivan the Terrible's conquest of the khanate of Astrakhan in 1556. Russia was now a Caspian power and became involved in the conflicts of the North Caucasus. In 1562, Tsar Ivan sent a five-hundred men force accompanied by an equal number of Cossack settlers. More parties of Cossacks continued to settle in the region. ${ }^{3}$

During the second half of the 18 th century, Prince Potemkin began to implement a sweeping plan to extent the Cossack line across the whole North Caucasus. Six-hundred mile long Caucasian mountain chain came under increasing Russian pressure. As Russian pressure increased, more and more Caucasians were ready to take their defence into their owns hands. Russian expansion in the North Caucasus met with protracted local resistance among the Chechens and Daghestanis. There the tsar's muskets were met with the 'Sabres of Paradise'. 4

'Sabres of Paradise' were a circle of Islamic mystics who belonged to the Naqshbandi Sufi brotherhood. Naqshbandi Sufi masters embraced an

\footnotetext{
${ }^{3}$ This brief summary is based on the following sources: M. Saray, ed., Kafkas Araştırmaları, I, Istanbul, 1988; I. Berkok, Tarihte Kafkasya, Istanbul, 1958; N.A. Sminov, Politika Rossii na Kavkaze v XVI-XIX Vekakh, Moscow, 1958; J.F. Baddeley, The Russian Conquest of the Caucasus, London, 1908.

${ }^{4} \mathrm{~L}$. Blanch, The Sabres of Paradise, London, 1960. This is a very colourful, historically accurate, but somewhat romanticised account of the Shamil's movement. For expatriate literature in Turkish, see T.M. Göztepe, Imam Şâmil, Kafkasya'nın Büyük Harp ve Ihtilâl Kahramanı, 1stanbul, 1961; A. H. Hizal, Kuzey Kafkasya, Ankara, 1961; A. Kunduk, Kafkasya Müridizmi, Istanbul, 1987; S.N. Tansu, Çağlara Baş Eğmeyen Dağlı: Şeyh Şamil, Istanbul, 1963; Z. Yetkin, I m a m Şâmil, Istanbul, 1986.
} 
active political role in the North Caucasus to defend Muslim communities against external pressures.

Sheikh Mansur, a Chechen shepherd, was one of the first leading Naqshbandi masters in the North Caucasus. By 1785 Mansur assumed the title of imam of all the Caucasian Muslims, and began to preach publicly for the eradication of all pre-Islamic practices, the replacement of customary law with the Shariat, and holy war against the Russians. For the Russian army it took more than five years to suppress the rebellion. ${ }^{5}$

The defeat and capture of Sheikh Mansur did not mean the end of the North Caucasians' struggle under the Naqshbandi influence. After a generation of interruption, the Naqshbandi movement revived in a more rigorous manner called as Muridism by the Russians. The word 'murid' refers to the disciple of a Sufi sheikh.

Beginning in the early years of the 19 th century, a series of three murid movements attempted to organise the Muslims of the North Caucasus. The third of these movements was led by the renowned Shamil. ${ }^{6}$

Truth and legend about Shamil's murids are so inextricably mixed that it is difficult to be sure where one ends and the other begins. Shamil's murids were told to have preferred death to having being disarmed. Shamil was said to be able to jump twenty-seven feet, and he was once seen to cleave a Cossack horseman to the saddle in one cut.

During the Crimean War it appeared that the struggle under Shamil had a chance of success. When Britain and France entered the war, Shamil envisioned a general Caucasian offensive against the Russians. ${ }^{7}$ But the early conclusion of the war in 1856 enabled the Russians to move against Shamil with further determination. After several years of fight his movement was isolated and Shamil was captured in $1859 .^{8}$

\footnotetext{
${ }^{5}$ C. Gökçe, Kafkasya ve Osmanlı Imparatorluğu'nun Kafkasya Siyaseti, Istanbul, 1979, pp. 247-253; T.C. Kutlu, Kuze y Kafkasya'nın llk Milli Mücahidi ve Önderi: Imam Mansur, Istanbul, 1987, pp. 42-45.

${ }^{6}$ The most comprehensive study of Shamil is M. Gammer, Muslim Resistance to the Tsar, London, 1994.

718 July 1856, B. A. Irade-Dahiliye, No. 26886, Osmanlı Devleti ile Kafkasya, Türkistan ve Kırım Hanlıkları Arasındaki Münasebetlere Dair Arşiv Belgeleri, Ankara, 1992, p. 11.

8 J. F. Baddeley, The Russian Conquest of the Caucasus, London, 1908.
} 
From this date up to the late 1930s, the Chechen lands and the North Caucasus witnessed a number of important resistance movements to the Russian and Soviet control. In almost all these movements, Islam in its Sufi form played a predominant role. The history of Chechnia in the Soviet priod was an almost uninterrupted succession of rebellions, uprisings, punitive counter-expeditions, individual terrorism, and religious fanaticism. In Soviet period, during the great anti-religious drives of the 1920s and 1930s, Sufism was not destroyed but went underground.

In February 1944, exactly fifty-one years ago, the entire population of Chechnia-Ingushetia, literally in the course of twenty-four hours, were arrested and embarked in prisoners' convoys for transport to unknown destination.

The names of towns, villages and regions were changed. Tens of thousands of Russians were settled on the lands of the Chechens and Ingush. ${ }^{9}$

Allegations that many Chechens and Ingush entered voluntarily into formations organised by Germans are almost certainly false. Cases of infiltration by individual German agents into Chechen-Ingush territory might have taken place. However, the Germans never entered Chechen-Ingush territory at any time. And they therefore never had direct contact with the population. A more likely motive seems to be the Soviet government's desire to eliminate all potential sources of rebellion in the region. The end of the war and the victory over Germany had provided an ideal opportunity for Stalin to even the scores with the rebellious North Caucasians.

Chechens and Ingush were indeed rebellious. They did not forget their homeland or lose their resentment at the manner in which they had been expelled from it by Stalin. During their exile, the Chechens and Ingush continued their resistance. According to Alexander Solzhenitsin who was together with them in the camps in Kazakhstan:

"There was one nation which would not give in, would not acquire the mental habits of submission - and not just individual rebels among them, but the whole naton to a man. These were the Chechens...I would say that of all the special settlers, the Chechens alone showed themselves zeks in spirit. They had been treacherously snatched from their home, and from that day they believed in nothing. They built themselves sakli - low, dark, miserable huts that looked as if you could kick them down. Their husbandry in exile was all of this sort - all just

${ }^{9}$ The standard works on Stalin's deportation during the Second World War of the North Caucasians, as well as the Volga Germans, Crimean Tatars and Meskhetians, are Conquest, The Nation Killer: The Soviet Deportation of Nationalities and A.M. Nekrich, The Punished Peoples, London, 1978. 
for a day, a month, a year, with nothing put by, no reserves, no thought for the future. They ate and drank, and the young people even dressed up. The years went by - and they owned just as little as they had to begin with. The Chechens never sought to please, to ingradiate themselves with the bosses; their attitude was always haughty and indeed openly hostile...They tried wherever possible to find themselves jobs as drivers: looking after an engine was not degrading, their passion for rough riding found an outlet in the constant movement of a motor vehicle, and their passion for thieving in the opportunities drivers enjoy. This last passion, however, they also gratified directly. 'We have been robbed', 'We have been cleaned out,' were concepts which they introduced to peaceful, honest, sleepy Kazakhstan...As far as they were concerned, the local inhabitants, and those exiles who submitted so readily, belonged more or less to the same breed as the bosses. They respected only rebels." 10

Soviet specialists of anti-Islamic propaganda recognised that the attempted genocide of over a million North Caucasian Muslims had a striking and unforeseen result: far from destroying the Sufi brotherhoods, the deportation actually promoted their expansion.

In 1956, three years after Stalin's death, Khrushchev launched his campaign of 'de-Stalinisation' at the 20th Party Congress. Chechens, Ingush, Balkars, Karachai and Kalmyks were rehabilitated during the congress. ${ }^{11}$

The Chechen people were allowed to return to their homeland in the $1960 \mathrm{~s}^{12}$ When they came back to Chechnia, Chechens seemed to be more nationalistic and religious than ever. The restrictive measures taken by the Soviet authorities promoted the missionary work and contributed to the development of clandestine brotherhoods among the Chechens. For the deported Chechens the Sufi orders became a symbol of nationalism and resistance. During the period after the Second World War Soviet sources continuously referred to the Chechens as 'the most religious' of all Soviet Muslims due to a long tradition of holy war.

The Soviet invasion of Afghanistan in 1979 had a powerful impact in Muslim peoples of the Soviet Union. The war led to an appreciable rise in Islamic feelings. Attendance to mosques rose, more people were applying to undertake religious studies, and many others joined secret Sufi brotherhoods.

${ }^{10}$ A. Solzhenitsin, The Gulag Archipelago, London, 1978, translated from Russian, pp. 401-2.

${ }^{11}$ Khrushchev's speech made no reference to the Volga Germans, Crimean Tatars and Maskhetians (the Ahiska Turks).

12Pravda, 12 February 1957. 
In the North Caucasus, a common religious bond with the Afghan guerillas aroused strong sympathy. North Caucasian recruits proved to be extremely reluctant to fight in Afghanistan. Solidarity with the Afghans was particularly strong among the Chechens. In June 1985, for instance, a number of Chechen recruits arrived Astrakhan for army service. When they were told that they would be trained for Afghanistan, they clashed with military authorities. ${ }^{13}$

Gorbachev's coming to power in March 1985 was more than a signal for a deep-rooted change for the Russian society. As glasnost and demokratizatsia made the Soviet Union a more open society, nationalities question boiled over. The new openness allowed national feelings and desire for further rights to expand and feed one another in a chain reaction of major and minor incidents that never seemed to stop. Both Russians and nonRussians alike took advantage of glasnost to express previously unspoken views on national culture, cross-national relations and religious freedom.

As a result, Gorbachev's agenda for perestroika was blockaded by various nationalist and religious separatist movements. Gorbachev was left struggling to find a formula by which he could reconcile minority ethnic demands for independence with the mainenance of the territorial and political unity of the Soviet Union. Despite Gorbachev's remarkable political skills, such a formula proved to be stubbornly evasive.

\section{War in Chechnia:}

As the Soviet Union prepared to enter the 1990s, the non-Russian nationalities remained to be a boiling cauldron that refused to cool down. There were increasingly strong pressures from non-Russian nations for a greater degree of control over their own affairs.

The North Caucasians too scized on the opportunity that had been created by the disintegration of the Sovict Union to maintain their rights and to create a situation which could provide better guarantees for future.

In Chechnia, a popular front, 'the National Chechen Congress', has been in existence since November 1990. It aimed to unite all the republican elements ranging from the liberal democratic opposition to the communist establishment. The initial aims of the Congress were modest, mainly to raise the status of their country from 'autonomous' to 'union' republic, and to be able to sign a union treaty with the USSR on an equal basis with the other fifteen former union republics.

\footnotetext{
${ }^{13}$ S. Khovanski, "Afghanistan: The Bleeding Wound", Detente, 6 (Spring 1986).
} 
Soon after its formation the 'National Chechen Congress' elected an Executive Committee with General Dzhokhar Dudaev as its chairman. Dudaev, born in January 1944, a few weeks before the deportation, in the village of Yakhovs in Chechnia, had been brought up in Kazakhstan where he was deported to with his parents. Soon after his return to Chechnia in 1957, Dudaev had attended evening school and gone to study at the Military Aviation School in Tambov. He had served in Siberia and the Ukraine. He was the commander of the strategic bomber division at Tortu in Estonia when he was invited back to Chechnia by the National Congress in late 1990 .

He was driven to power by a somewhat exceptional set of circumstances. In 1991 he was clearly recognized as a Yeltsin supporter and a person who could act against the conservative leadership in the ChechenIngush Republic. The events in the republic, however, moved too fast and the initial expectation of Yeltsin administration soon appeared to be not so reliable.

The ascelation of events in the Chechen-Ingush Republic started on 19 August 1991 with the putsch in Moscow by the Yanayev junta which sealed the fate of the Soviet Union and resulted in power slipping from Mikhail Gorbachov's hands to those of Boris Yeltsin. On hearing the news, the National Chechan Congress issued an appeal and called the people of the Chechen-Ingush Republic to declare an indefinite general political strike, and to display civil disobedience until the arrest of the 'criminal junta', ${ }^{14}$

On 26 August 1991, Moscow Central Television transmitted the address of Nursultan Nazarbaev, the President of Kazakhistan, to the first session of the USSR Supreme Soviet after the failed coup. Nazarbaev expressed the feelings of most of the non-Russian citizens of the Soviet Union regarding their future participation in the union. Significantly for the Chechens and the Ingush, Nazarbaev put forward his vision:

"How do I envisage that future union? Having entered into contractual economic agreements among ourselves, we republics have in mind broad economic relations with everyone who agrees to that...We are used to the abbreviation 'USSR'. I propose leaving it and changing it to the 'Free Union of Sovereign Republics'...By republics I have in mind all republics, including the autonomous ones which have declared themselves sovereign, and those which will want to do so...In other words, we are proposing that a confederative treaty be concluded. I am

\footnotetext{
${ }^{14}$ Published by the weekly independent newspaper Svoboda (Groznyi), 1, 28,
} 30 August 1991 
convinced that only then shall we attain genuine equality for the republics..." 15

This encouragement gave the green light to the Chechen nationalists. Promptly the next day, on 27 August, the All-Union Radio monitored by the $\mathrm{BBC}$ reported an uprising in the Chechen-Ingush Republic. ${ }^{16}$ The airport of Groznyi had been blocked in order to stop the leaders of the Republic running away. The television and radio stations and a range of other administrative government buildings had been controlled by the demonstrators. Delegations from every town and village of the Republic were pouring into Groznyi to support the insurgents. On 1 September the buildings of the Council of Ministers and Parliament were seized by the National Chechen Congress. Russian radio reported that the green flag of Islam had been raised above these buildings. It was also stated that "the events in the Chechnia-Ingushetia had been provoked by pro-Islamic nationalist activists..."17

After this date, the Chechen opposition became increasingly aggressive. General Dudaev declared that the Presidium's resolution was a declaration of war on the Chechen-Ingush Republic. Chechen National Congress proclaimed a general mobilisation of the Chechen malc population aged between fifteen and fifty-five. On 16 October the Chechen National Congress announced the introduction of Chechen citizenship, and two days later General Dudaev urged his people to prepare for war.

On 27 October 1991, the Executive Committee of the National Chechen Congress organised and held presidential and parliamentary elections which were considered illegitimate by the Congress of People's Deputies of the RSFSR. ${ }^{18}$ Dudaev's victory in the elections and the declaration of independence was challenged by Boris Yeltsin who issued a warrant for Dudaev's arrest and sent Russian troops to Chechnia. Such incidents fuelled the Chechens' anti-Russian, nationalist rhetoric, and provided a unifying rallying point for almost all Chechen nationalists. The events subsequently developed into a volatile and confrontational power struggle between Groznyi and Moscow.

Widespread disturbances accompanied with an intense propaganda war went on for about three years until December 1994 when a full scale military operation erupted in Chechnia. Russia's recent debacle in the North Caucasus

${ }^{15}$ Central Television, First All-Union Programme, 1300 GMT, 26 August 1991, excerpts from the BBC SWB SU/ 1162 C1/ 7, 28 August 1991.

${ }^{16}$ SWB SU/ 1163 ii, 29 August 1991.

${ }^{17}$ SWB SU/ 1168 ii, 4 September 1991.

${ }^{18}$ Resolution of 2 November 1991, 'Facts sheet about the Chechen Republic', issued by the Russian Embassy in London, 23 January 1995. 
began with a declaration on Russian television on 27 November 1994: Chechen rebels had seized the presidential palace in Groznyi, and driven the Dudaev's 'bandits' from power. The story quickly unravelled. Presidential palace had not been taken, Dudaev had not fled, and the attackers were not 'rebels' but the Russian soldiers. All this had indeed been an unsuccessful covert operation by the Russian army. The full-scale military assault, Russia's biggest offensive military action since the invasion of Afghanistan, was launched on 11 December. 19

\section{The Past in The Present - 'New Colonialism'?}

In December 1994, when thousands of Russian soldiers were storming the Chechen capital, Russian Prime Minister Victor Chernomyrdin was accusing the Chechens for "stirring up nationality-based and religious discord..." 20 Similarly Yeltsin described Russia's actions in Chechnia using a terminology which had much in common with that of the Stalinist period. According to Yeltsin, the Russian Federation started military operations because Chechnia "has become the center of gravity for all extremist and nationalist forces..." and the criminals "have found refuge in the Chechen Republic." 21

The assault on Chechnia destroyed all remaining hopes for a peaceful station. The entire campaign fed on the same rhetoric that drove Russia's many past campaigns to conquer the North Caucasus: the task was no longer mercly to subdue, but to destroy. Sergei Stepashin, chief of the renamed $\mathrm{KGB}$, did not conceal the intention: "All those who attempt to resist will be eliminated." 22

In addition to the loss of life and material damage that were incurred, the Russian military campaign polarised positions, making any compromise with the hard core of the Chechen nationalists increasingly difficult. It also enabled the Chechen nationalists to enlist elements which were originally foreign to their constituencies, thus meaningfully broadening their power base. Russian military intervention has legitimised the Chechen separatists in a struggle where the tactics of the Russians in the assault of Groznyi and in the Chechen hills often deserve a terrorist label. The Chechen 'rebels', in

${ }^{19}$ The Independent Magazine, 14 January 1995, p. 21.

${ }^{20}$ Rossiiskaia Gazeta, 15 December 1994, pp. 1-2.

${ }^{21}$ Rossiiskaia Gazeta, 29 December 1994, pp. 1-2. These and other similar comments in the Russian media are extraordinarily similar to those published in Stalin's last years. Especially in late 1952, more and more references had been made to the North Caucasian Muslims as the "nations of criminals" (Izvestiia, 25 November 1952; Pravda, 10 December 1952.)

${ }^{22}$ The Independent Magazine, 14 January 1955, p. 21. 
this way, has acquired by virtue of Russian suppression the character of a movement of national liberation.

Chechnia is of strategic importance to Russia. Chechen lands have vast mineral and other natural resources. Existing oil pipe-lines make Chechnia Russia's Kuwait. It is the gateway to the entire Caucasus, a region which Russia wants to maintain its sphere of influence.

In January 1992, Moskovskie Novosti published and article written by M. Shevelev. Shevelev proposes to reassess the significance of "new colonialism". He thinks that the new colonialism is a "better evil" than the old style classical colonialism which was based on naked coercion. Shevelev argues that if Russia succeeds in enforcing new colonialistic policies, it would be good for Russia and for ex-Soviet republics. ${ }^{23}$

Shevelev's argument about new colonialism as a better evil draws clear and direct parallels with the debate about the Russian annexation of the North Caucasus and Shamil's resistance movement. It touches on an important point: What is the strategic relevance of diki vostok (backward Orient) to Russia? Whether as a tsarist state, communist state, or a postcommunist state, for Russia North Caucasus is of strategic importance. North Caucasian lands have vast mineral and other natural resources. It is the gateway to the entire Caucasus, a region which Russia wants to maintain its sphere of influence. The debate on Shamil is directly related to a pronounced Russian desire and willingness to protect its historic-political-strategic interests in the North Caucasus.

For many Russians, the Chechen lands are a place of exotica and inaccessible cultures. The separatist aspirations of the North Caucasians dismayed the Russians. They have always despised their Muslim adversaries. They considered these fanatical fighters as stupid, primitive, and always treated them as rebels and bandits. This was true in the 18th century. And it has been true for every Muslim military and political opponent of Russia cver since.

Soviet sociologists classified them as 'extreme fanatics', 'bandits', and 'terrorists'. The Soviet press provides rich material on the numerous trials of Sufi sheikhs and their murids in the late fifties and sixties. As a rule, the accused were tried for 'banditry' and 'manslaughter'.

As a result of such high-handed comtempt, the Russians were unable to understand their adversaries, their motivation, strategy, and ideology. Russian leaders on the face of the evidence should have learned a good deal from history. But they appear to have chosen to ignore it. One is struck by

${ }^{23}$ Moskovskie Novosti, 4, 26 January 1992, p. 8. 
the repetition of the same recipes and mistakes in the military and political field for the last two-hundred years.

Important also is the psychological heritage of the 19th century Caucasian wars on the Russian mind. No other wars have left such a profound and long-lasting impression on Russian culture and folklore. The most celebrated poems of Pushkin and Lermontov, and some of Tolstoy's fiction, were seen in the rough landscape of the North Caucasus. A Russian lullaby, a poem by Lermontov, sung by mothers to their newborn sons, depicts a cruel Chechen creeping along the bank of the Terek River and sharpening his dagger to kill the child.

A century and-a-half after Lermontov, from the 1970s onwards, thousands of Russians started to emigrate from Chechnia and Daghestan unable to cope with the xenophobia of the local population. The legacy of two centuries of warfare is heavy. Chechnia remains a symbol both of Russia's political failure and its moral failure. This is why many Russian historians, even under glasnost, and even after the end of the Soviet system, continue to pretend that the Caucasian wars, the Stalin deportations were all duc to the misdeeds and banditry of the Chechens themselves. It may therefore prove particularly difficult for the Russians to accept disengagement from the North Caucasus, more so than from the Baltic Republics, Transcaucasia and even Central Asia.

During the more than four years since the callapse of the Soviet Union, the Russian Federation has been attempting to restructure its political, economic, and social system. Underlying this structural transformation has been an effort to define a new Russian identity. Today, Russians are in an ever-increasing scarch for their own identity. The break-up of the Soviet Union caused a tide of Russian nationalism. It is now popular to talk about a mono-ethnic Russia, a state of blood, a state of soil. Almost all groups of the present-day Russian Parliament are overtly or covertly trying to exploit the 'Great Russian idea'. In the absence of an all embracing visionary ideology and in the context of the current deep crisis, the outdated and nostalgic 'Great Russian' nationalism has re-emerged as an unstable amalgam of the glorious Russian past and the authoritarian Stalinist legacy.

It is ironic that post-Soviet Russian leadership, who have done everything possible to speed up the Soviet Union's break-up in many ways, cannot handle the outcome of this disintegration. In the Summer of 1990, Yeltsin had called on minority peoples to take as much power as they wanted. This call later proved to be problematic for himself.

Stalin disappeared long ago. The totalitarian political system, which was represented by Stalin in its extreme, is now in the domain of the past. Yet, despite the new face and image, the present-day Russian political culture 
continues to derive the inspirations for its tactics and strategies from Stalinist calculations and manipulations.*

\footnotetext{
* I am indebted to Professor John Erickson who drew my attention to a recent collection of essays published in Rodina $(3-4,1994)$ on the 19 th century North Caucasian wars.
} 